\title{
The Effect of Aerosolization upon Survival and Potassium Retention by Various Bacteria
}

\author{
By J. D. ANDERSON*, F. A. DARK AND S. PETO \\ Microbiological Research Establishment, Porton, Salisbury, Wiltshire
}

(Accepted for publication 28 November 1967)

\begin{abstract}
SUMMARY
Previous studies with populations of Escherichia coli strain B, recovered from aerosols, showed that, of the biochemical changes which were shown to precede death, the most dramatic was a rapid loss of ability to maintain cellular potassium concentrations. Loss of control over potassium may cause or contribute to death in bacteria recovered from aerosols and also probably implies a loss of control over other ions and substrates. Potassium ion efflux studies with this organism have been extended here to $E$. coli var. communis, E. coli strain JEPP, Aerobacter aerogenes strain H, Serratia marcescens strain $8 \mathrm{UK}$ and Staphylococcus epidermidis strain NCTC 729r. After aerosolization all these organisms rapidly lost ability to retain intracellular potassium, as a consequence of damage initiated in the aerosol. Evidence for a positive correlation between survival and potassium retention was found over a limited range of conditions for most of the organisms examined. The significance of these results in relation to death processes in aerosolized bacteria is discussed.
\end{abstract}

\section{INTRODUCTION}

Loss of ability to synthesize an inducible protein, and loss of control over phosphate and potassium ions appears to precede death in populations of Escherichia coli strain B which have been recovered from aerosols. These changes in $E$. coli strain B are thought to precede death because their relative extent is generally far greater than the corresponding loss of viability, and because of evidence for correlations between survival and certain of the changes. These changes are also thought to be partly reversible because populations which are substantially viable may be recovered from aerosols under certain conditions and yet have undergone a temporary disruption of normal biochemical processes (Anderson, 1966; Anderson \& Dark, 1967). The disruption is probably not due to generalized denaturation of protein because the $\beta$-galactosidase of $E$. coli strain $\mathrm{B}$, which is a convenient and representative protein to study, is unaffected by aerosolization (Anderson, 1966; Anderson \& Crouch, 1967). Of the metabolic changes observed in populations recovered from aerosols of $E$. coli strain $\mathrm{B}$, a rapid loss of ability to control cellular potassium concentrations was the most dramatic consequence of aerosolization. Since loss of control over $\mathrm{K}^{+}$could be directly or indirectly lethal and implies a general disorganization of bacterial ion and substrate transport mechanism, $\mathrm{K}^{+}$movements merit particular attention. Studies with $E$. coli strain в have therefore been extended here to other strains of this organism, and to other species in order to discover whether phenomena observed with $E$. coli

* Present address: The Medical School, University of Bristol, Bristol 2. 
strain $\mathrm{B}$ are of general occurrence. Evidence for correlations was looked for between the age and relative humidity of the bacterial aerosol, the survival on recovery, and the extent of the rapid loss of potassium into the collecting fluid.

\section{METHODS}

The apparatus, materials and methods used here for the study of six organisms were similar to those already described for studies of efflux of $\left[{ }^{43} \mathrm{~K}\right]$ from populations of Escherichia coli strain B (Anderson \& Dark, 1967). Therefore only a brief outline of the methods is given here.

Organisms. Cultures of Aerobacter aerogenes strain H, Escherichia coli strains B, JEPP, E. coli var. communis, Serratia marcescens strain $8 \mathrm{UK}$ and Staphylococcus epidermidis NCTC 729I were grown from freeze-dried stocks and maintained in a liquid meat broth medium.

Radiolabelled bacterial suspensions were prepared by re-incubation of concentrated suspensions of resting phase organisms in 'low potassium', $\left[{ }^{43} \mathrm{~K}\right]$-labelled tryptone medium. The radio-isotope was determined with a solid crystal scintillation counter.

Determination of bacterial survival values. Total numbers of bacteria recovered from aerosols were calculated from the viable organism count and the radiotracer content of the impinger samples, and the viable and radiotracer content of unsprayed suspensions. In general, samples of unsprayed suspensions removed from the spray pot before each experiment served as a control and were given a nominal viability of $100 \%$. Suspensions of Staphylococcus epidermidis in distilled water tended to clump slightly; material which had undergone violent agitation in the spray pot was therefore sampled at the end of each experiment, as a control. Plate counts and radio-tracer determinations were made under conditions whereby survival estimates generally had a $95 \%$ confidence belt of better than $\pm 10 \%$ of observed values.

Apparatus for the study of bacterial aerosols. Monodisperse aerosols were generated from aqueous suspensions of bacteria by using an air-blast atomizer, then mixed with a further supply of air to give the desired relative humidity and stored in a rotating drum (Goldberg, Watkins, Boerke \& Chatigny, 1958). Samples containing about $3 \times 10^{6}$ organisms $/ \mathrm{ml}$. were collected into 'raised Porton impingers' (May \& Harper, I957) containing phosphate buffer + alginate (Henderson, I952).

Determination of the rate of loss of $\left[{ }^{43} \mathrm{~K}\right]$ from labelled organisms. The extent of $\left[{ }^{43} \mathrm{~K}\right]$ efflux from controls and from populations recovered from aerosols was determined at various times after collection by filtration of portions of impinger samples through membrane filters. Estimates of the $\left[{ }^{43} \mathrm{~K}\right]$ content of bacterial samples generally had $95 \%$ fiducial limits of less than $\pm 5 \%$.

\section{RESULTS AND DISCUSSION}

Table I shows that the procedure for labelling the bacteria was satisfactory and that in all cases only a small proportion of radiotracer could be removed from the organisms by merely washing with water. Any sudden loss of ability to retain $\left[{ }^{43} \mathrm{~K}\right]$ in aqueous suspension thus indicated a breakdown of normal ion control processes.

Aerosols generated from washed suspensions of the different bacteria were stored at various relative humidities. At each relative humidity value bacterial samples were 
recovered from the aerosol cloud into impingers at $\mathrm{I} \cdot 2 \mathrm{sec}$., 5 and $30 \mathrm{~min}$. after generation. The $\left[{ }^{43} \mathrm{~K}\right]$ content of each of these populations, and of unsprayed controls, was determined at 2, 15 and $30 \mathrm{~min}$. after the mean time of sampling. All the bacterial species examined suffered a rapid initial loss of radiotracer followed by a very much slower loss. The plot of $\log \left[{ }^{43} \mathrm{~K}\right]$ content versus time after recovery from the aerosol was practically linear for the three sampling times (2, I5 and $30 \mathrm{~min}$.). The rate of this slower loss could not be accurately determined because of the comparatively large, but

Table I. Incorporation of $\left[{ }^{43} \mathrm{~K}\right]$ and loss by suspensions of various bacteria

$\begin{array}{cc} & \begin{array}{c}\text { Amount of labelled } \\ \text { ion remaining in }\end{array} \\ \text { Uptake of labelled } & \text { organisms after one } \\ \text { ion }(\% \text { of the } & \text { wash with water } \\ \text { amount added } & (\% \text { of the amount } \\ \text { to growth } & \text { added to } \\ \text { medium }) & \text { growth medium })\end{array}$

Escherichia coli strain B

E. coli var. communis

$64 \quad 55$

E. coli strain JEPP

Aerobacter aerogenes

Serratia marcescens

Staphylococcus epidermidis

$47 \quad 40$

$34 \quad 26$

$70 \quad 50$

$68 \quad 54$

$37 \quad 33$

Table 2. Effect of vigorous 'washing' processes in the spray pot upon the value of the 'initial' $\left[{ }^{43} \mathrm{~K}\right]$ efflux from aqueous suspensions of various bacteria

\begin{tabular}{|c|c|c|}
\hline $\begin{array}{c}\text { Organism (number of determinations in } \\
\text { parentheses) }\end{array}$ & $\begin{array}{l}\text { Mean value of } \\
\left.\text { 'initial'*[43 }{ }^{43}\right] \\
\text { efflux }(\%) \text { from sus- } \\
\text { pensions taken from } \\
\text { the spray pot } \\
\text { before each } \\
\text { experiment }\end{array}$ & $\begin{array}{l}\text { Mean value of } \\
\text { 'initial' } *\left[{ }^{43} \mathrm{~K}\right] \\
\text { efflux }(\%) \text { from sus- } \\
\text { pensions taken from } \\
\text { the spray pot } \\
\text { after each } \\
\text { experiment }\end{array}$ \\
\hline Escherichia coli strain в (I3) & $5 \cdot 8$ & $8 \cdot 3$ \\
\hline E. coli var. communis $(6)$ & $6 \cdot 5$ & $6 \cdot 7$ \\
\hline E. coli strain JEPP (7) & 0.5 & I4 \\
\hline Aerobacter aerogenes (10) & $9 \cdot 0$ & 18 \\
\hline Serratia marcescens $(8)$ & $4 \cdot 0$ & $8 \cdot I$ \\
\hline Staphylococcus epidermidis (6) & $5 \cdot 0$ & $5 \cdot 5$ \\
\hline
\end{tabular}

statistically acceptable, scatter in individual radiotracer determinations. Intercepts (at zero time) of the plots of $\log \left[{ }^{43} \mathrm{~K}\right]$ content versus time were calculated for all species both for the unsprayed 'controls' and for samples which had been recovered from aerosols. Since the $\left[{ }^{43} \mathrm{~K}\right]$ content of bacterial populations could not be conveniently measured at less than 2 min. after the mean sampling time, the intercept of 'initial' value for potassium loss obtained from the plot of $\log \left[{ }^{43} \mathrm{~K}\right]$ content against time was used as a measure of the extent of the initial rapid loss of potassium which followed recovery from the aerosol. The extent of the 'initial' $\left[{ }^{43} \mathrm{~K}\right]$ loss was regarded as a measure of the degree of failure of mechanisms responsible for the retention of this ion. This 'initial' loss of $\left[{ }^{43} \mathrm{~K}\right]$ by Escherichia coli strain B has already been shown (Anderson \& Dark, I967) to be a net loss of this ion rather than a facilitated exchange between the radio- 


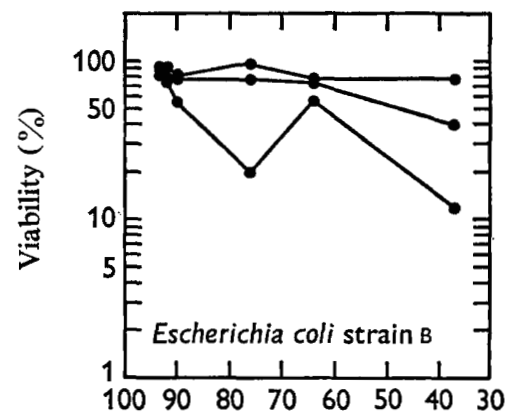

Relative humidity (RH)

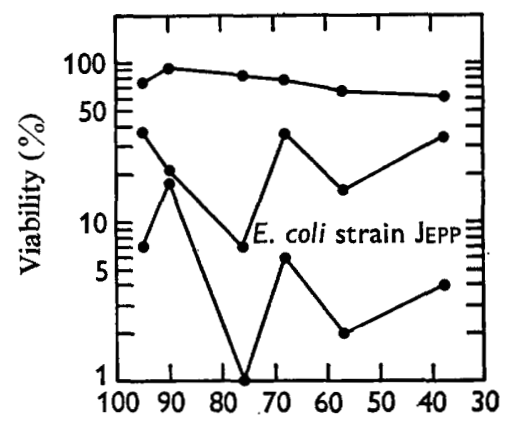

RH

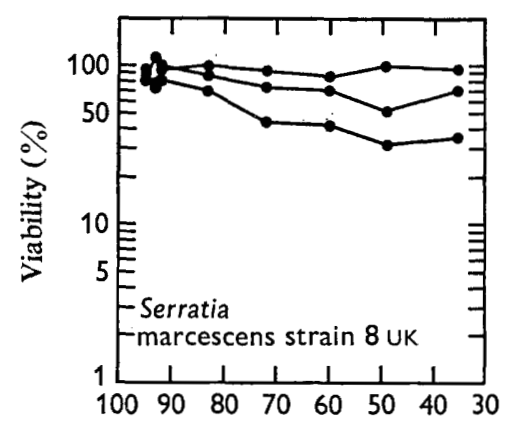

Serratia marcescens strain $8 \mathrm{UK}$

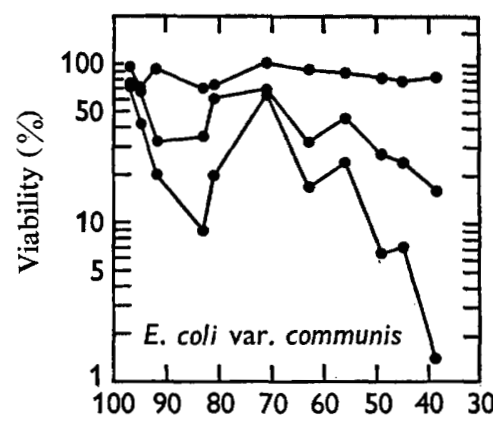

RH

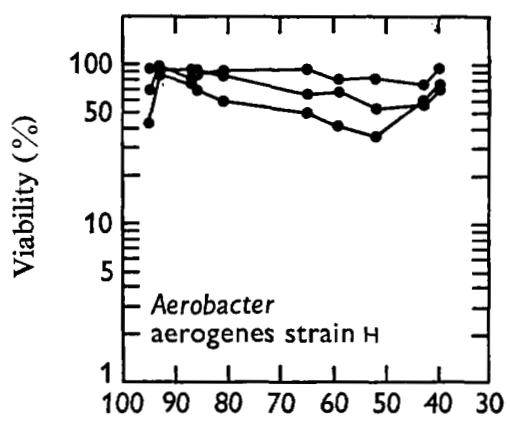

RH

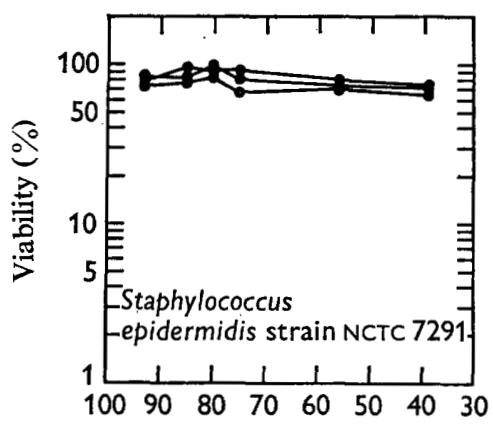

Staphylococcus epidermidis NCTC 7291

Fig. I. The effect of relative humidity $(\mathrm{RH})$ and aerosol cloud age upon the survival of various bacteria. In each case the plots represent (reading downwards) survival of populations recovered from aerosols into impingers at $I \cdot 2 \mathrm{sec} ., 5$ and $30 \mathrm{~min}$. after generation.

tracer and the unlabelled ion of the fluid into which the bacteria were recovered. Although the kinetics of $\left[{ }^{43} \mathrm{~K}\right]$ loss by $E$. coli strain B have already been described in detail certain results obtained with this strain will be reiterated here for this comparative survey.

The 'initial' loss of $\left[{ }^{43} \mathrm{~K}\right]$ from aqueous bacterial suspensions which were diluted in phosphate buffer+alginate collecting fluid was comparatively small and was not 
greatly increased by violent agitation in the spray pot for 3 min. during the course of each experiment (Table 2). By contrast, 'initial' $\left[{ }^{43} \mathrm{~K}\right]$ losses observed from populations recovered from aerosols were much larger and might be a result of aerosolization. A correlation was therefore looked for between 'initial' $\left[{ }^{43} \mathrm{~K}\right]$ retention, the survival of organisms and the age and relative humidity of the bacterial cloud.

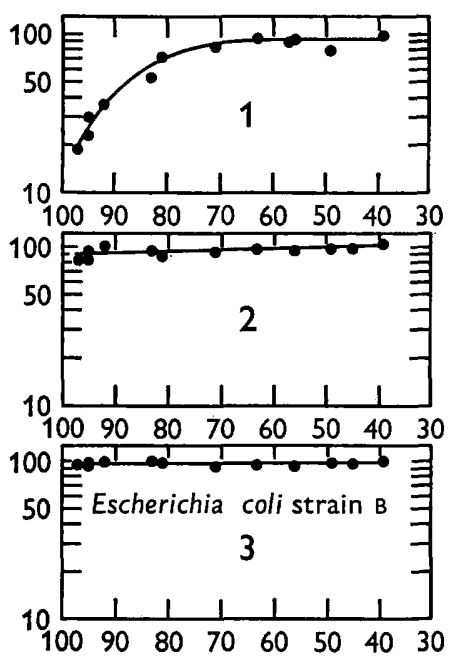

RH
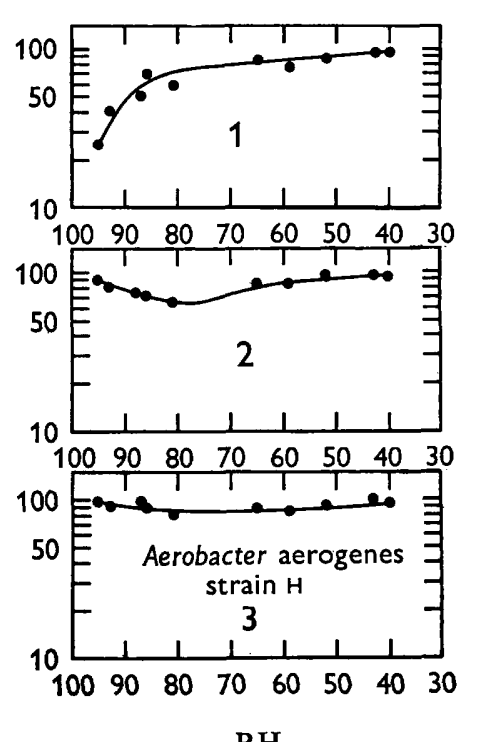
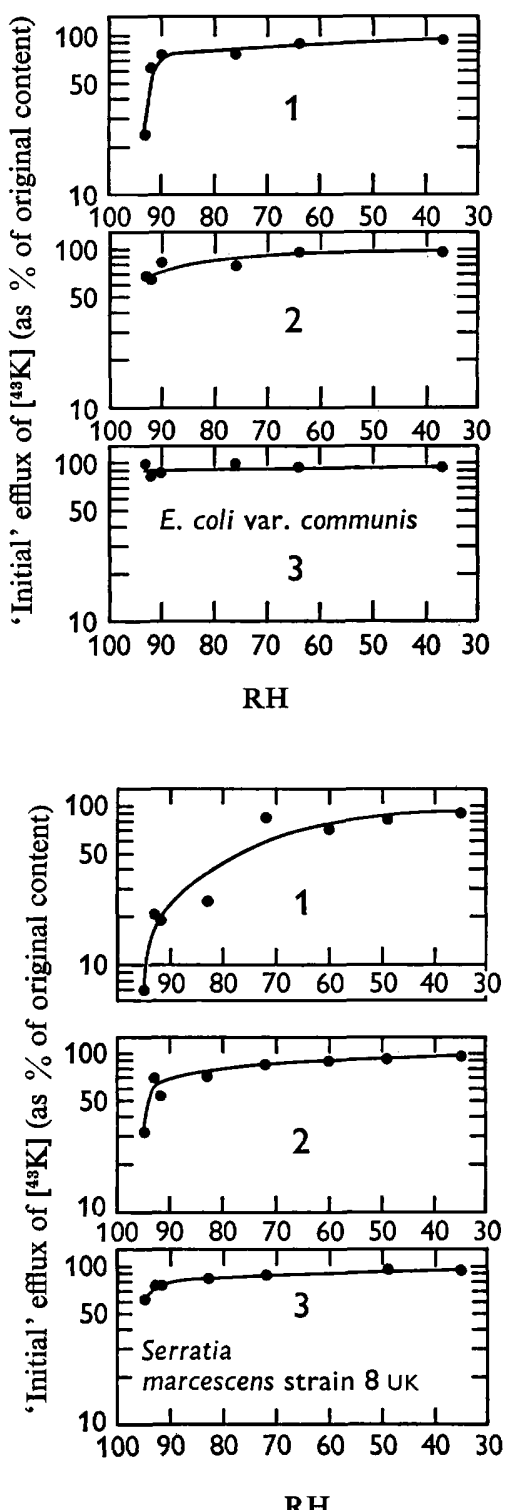
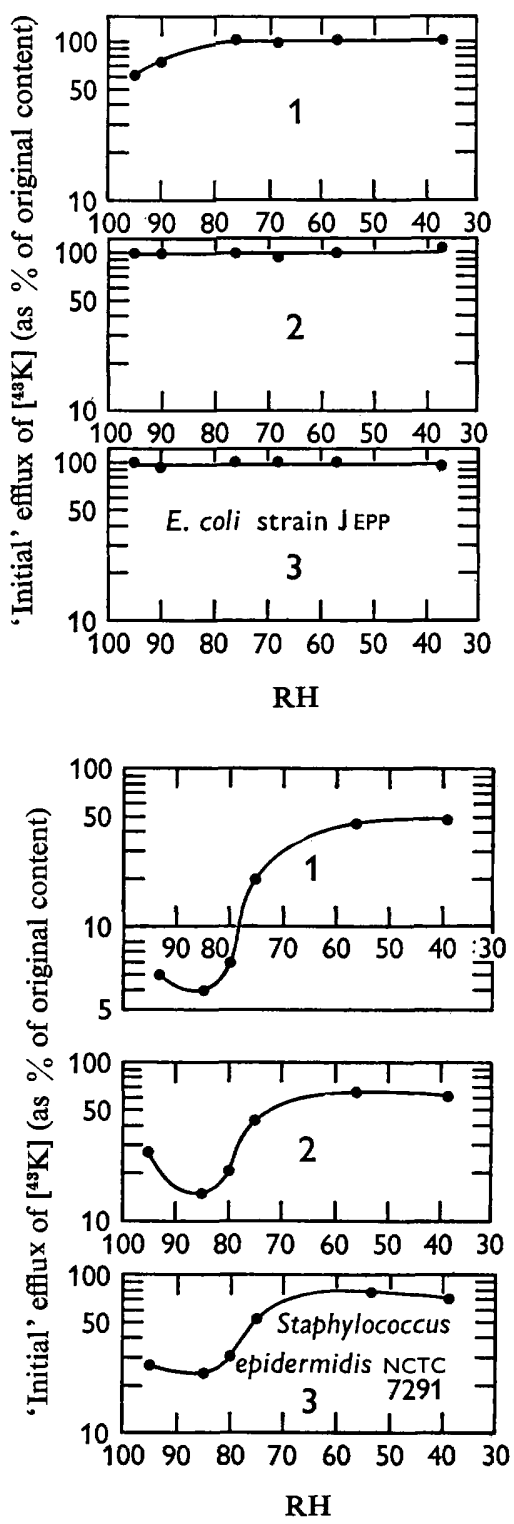

Fig. 2. The effect of relative humidity $(\mathrm{RH})$ and aerosol cloud age upon the 'initial' efflux of $\left[{ }^{43} \mathrm{~K}\right]$ from labelled populations of different bacteria. For each organism plots $\mathrm{I}, 2$ and 3 represent respectively results obtained with populations recovered from aerosols into impingers at $I \cdot 2 \mathrm{sec} ., 5$ and $30 \mathrm{~min}$. after generation. 
Fig. I. summarizes the effect of relative humidity and holding time in the aerosol upon the survival of aerosolized bacteria. Aerosols of Escherichia coli strain B and of other organisms may be particularly unstable at certain narrow ranges of relative humidity values (evidence reviewed by Anderson \& Cox, 1967). The apparent absence of such zones of instability for the organisms described in Fig. I may be due to dif-

Table 3. Evidence for a correlation between the 'initial' efflux of $\left[{ }^{43} \mathrm{~K}\right]$ from bacteria recovered from aerosols and the relative humidity of the bacterial cloud

\begin{tabular}{|c|c|c|c|}
\hline \multirow{2}{*}{$\begin{array}{l}\text { Organisms (number of separate } \\
\text { relative humidity values } \\
\text { studied in parentheses) }\end{array}$} & \multirow{2}{*}{$\begin{array}{l}\text { Relative } \\
\text { humidity } \\
\text { range }(\%) \\
\text { studied }\end{array}$} & \multicolumn{2}{|c|}{$\begin{array}{l}{ }^{*} \text { Correlation coefficients of plot } \\
\text { of }\left[{ }^{43} \mathrm{~K}\right] \text { retention ( } 100-\text { 'initial' } \\
\text { efflux) versus relative humidity }(\%) \\
\text { for populations recovered from } \\
\text { aerosol clouds at the following } \\
\text { times after generation }\end{array}$} \\
\hline & & $\mathbf{I} \cdot 2 \mathrm{sec}$ & $5 \mathrm{~min}$. \\
\hline Escherichia coli strain B (I 2) & $39-95$ & $0.91(0.1 \%)$ & $0.62(5 \%)$ \\
\hline E. coli strain communis (6) & $37-93$ & - & $0.84(5 \%)$ \\
\hline E. coli strain JEPP (6) & $38-95$ & - & - \\
\hline Aerobacter aerogenes (Io) & $40-95$ & $0.91(0.1 \%)$ & $0.69(5 \%)$ \\
\hline Serratia marcescens (8) & $35-95$ & $0.90(1 \%)$ & $0.84(1 \%)$ \\
\hline Staphylococcus epidermidis (6) & $39-93$ & $0.94($ I \%) & $0.88(5 \%)$ \\
\hline
\end{tabular}

* Significance levels are shown in parentheses; other correlation coefficients, although positive in most cases, were found to be not significant and are not shown.

Table 4. Summary of the significant results of an investigation into a correlation between the extent of the 'initial' loss of $\left[{ }^{43} \mathrm{~K}\right]$ and the survival of organisms recovered from aerosols

\section{Organism}

Escherichia coli strain B

E. coli strain communis

E. coli strain JEPP

Aerobacter aerogenes

Serratia marcescens

Staphylococcus epidermidis
Age of aerosol cloud (min.)

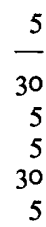

$$
\begin{aligned}
& \text { *Correlation coefficients } \\
& \text { of plot of }\left[{ }^{43} \mathrm{~K}\right] \text { retention } \\
& \text { (I00- 'initial' loss) versus } \\
& \text { viability ( } \%) \text { for popula- } \\
& \text { tions recovered from } \\
& \text { aerosol clouds }
\end{aligned}
$$

$$
\begin{aligned}
& 0.74(10 \%) \\
& 0.88(5 \%) \\
& 0.84(1 \%) \\
& 0.78(5 \%) \\
& 0.97(0.1 \%) \\
& 0.84(5 \%)
\end{aligned}
$$

* Significance levels in parentheses; correlation coefficients not shown were found to be not significant.

ferences in cultural conditions or to the comparatively large increments of relative humidity at which survival values have been determined. In view of these uncertainties the survival patterns shown in Fig. I have not been represented as smooth curves, and may only be regarded as a rough indication of the relative stability of the organisms.

Figure 2 summarizes the effect of relative humidity and holding time in the aerosol upon the extent of 'initial' $\left[{ }^{43} \mathrm{~K}\right]$ loss at points corresponding to those of Fig. I. The 
general pattern of the results suggests that the extent of the 'initial' $\left[{ }^{43} \mathrm{~K}\right]$ loss increases with decreasing relative humidity.

Since loss of $\left[{ }^{43} \mathrm{~K}\right]$ was practically complete at $30 \mathrm{~min}$., correlation coefficients between the plot of $\left[{ }^{43} \mathrm{~K}\right]$ retention and relative humidity were generally only significant for the $\mathrm{I} \cdot 2 \mathrm{sec}$. and 5 min. samples (Table 3 ); $\left[{ }^{43} \mathrm{~K}\right]$ loss from Escherichia coli strain JEPP were so rapid that the corresponding correlation coefficients were not significant even for the $\mathrm{I} \cdot 2$ sec. sample; at the other extreme the same correlation coefficients (0.88 each) for Serratia marcescens and Staphylococcus epidermidis were significant ( $\%$ and $5 \%$ levels, respectively) even for the $30 \mathrm{~min}$. sample. The proven dependance of $\left[{ }^{43} \mathrm{~K}\right]$ efflux upon the age and relative humidity of the aerosol cloud shows that bacterial ion-control mechanisms were damaged as a result of changes which were initiated in the aerosol but which might, or might not, be expressed until the bacteria were recovered into aqueous media.

Since all the organisms were substantially viable when sampled from aerosols at $\mathrm{I} \cdot 2 \mathrm{sec}$. after generation, and most organisms sampled from aerosols at $30 \mathrm{~min}$. suffered an almost total 'initial' loss of $\left[{ }^{43} \mathrm{~K}\right]$ upon collection, a significant correlation between $\left[{ }^{43} \mathrm{~K}\right]$ retention and viability was only demonstrated over a limited range of conditions (Table 4; note the unsatisfactory significance level for Escherichia coli strain B). The partial dependence of survival upon $\left[{ }^{43} \mathrm{~K}\right]$ retention confirms that survival was not absolutely dependent upon the integrity of processes which retain potassium (Anderson \& Dark, 1967). Nevertheless, failure of such processes would undoubtedly contribute to death and imply a breakdown of mechanisms for the retention of other ions and substrates in all the different organisms examined.

We are most grateful to $\mathrm{Mr} \mathrm{I}$. H. Silver for his interest and encouragement, $\mathrm{Mr}$ R. E. Strange for his advice, Mr G. T. Crouch for experimental assistance and to Mr B. J. Maidment for all computations.

\section{REFERENCES}

ANDERSON, J. D. (I966). Biochemical studies of lethal processes in aerosols of Escherichia coli. J. gen. Microbiol. 45, 303 .

Anderson, J. D. \& Cox, C. S. (1967). Microbial survival. Symp. Soc. gen. Microbiol. 17, 203.

Anderson, J. D. \& Crouch, G. T. (1967). A new principle for the determination of total bacterial numbers in populations recovered from aerosols. J. gen. Microbiol. 47, 49.

ANDERSON, J. D. \& DARK, F. A. (1967). Studies on the effects of aerosolization on the rates of efflux of ions from populations of Escherichia coli strain B. J. gen. Microbiol. 46, 95.

Henderson, D. W. (1952). An apparatus for the study of airborne infection. J. Hyg., Camb. 50, 53.

Goldberg, L. J., Watkins, H. M. S., Boerke, E. E. \& Chatigny, M. A. (I958). The use of a rotating drum for the study of aerosols over extended periods of time. Am. J. Hyg. 68, 85 .

MAY, K. R. \& HARPER, G. J. (I957). The efficiency of various liquid impinger samplers in bacterial aerosols. Br. J. ind. Med. I4, 287. 